\title{
各種果実のアセトン可溶性画分が果実の 酵素的褐変に及ぼす影響
}

\author{
小宮山美弘 ${ }^{*}$ ・辻 政雄 ${ }^{*} \cdot$ 岩田 隆 ${ }^{* *}$ \\ Effect of Acetone Soluble Fraction from Various Fruits on \\ Enzymatic Browning \\ Yoshihiro KomiYama*, Masao TsuJ'* and Takashi Iwata** \\ * Department of Wine and Food Technology, Yamanashi Industrial \\ Technology Center, 312-4, Isawa-cho, Yamanashi 406 \\ ** College of Agriculture, University of Osaka Prefecture, 4 \\ Mozuume-machi, Sakai-shi, Osaka 591
}

\begin{abstract}
Polyphenol oxidase (PPO) of each fruit was added to each of acetone soluble fractions (AFs) prepared from various fruits, and the extent of browning of the reaction mixtures was determined. When the AFs from three fruits ('Delaware' grape, 'Sordum' plum, 'Hakuho' peach), containing the same amount of polyphenol, were added to PPO of each fruit, the AF of grape markedly inhibited PPO activity of all three kinds of fruit. The oxidation of the AF of peach was the strongest of the three and that of plum was intermediate. The PPO and AFs of 'Kosui' pear and 'Tsugaru' apple were also prepared by the same method as the other three fruits. Since the PPO of all five fruits had high substrate specificity for chlorogenic acid, the oxidation of chlorogenic acid was used as an index of the browning. The AF of grape inhibited PPO activity of peach, apple and grape, whereas the AF of plum inhibited PPO activity of peach and apple, but accelerated the PPO activity of pear, plum and grape. The AF of peach and apple was appeared to have a stimulative effect on PPO activity.

(Received Jul. 11, 1990)
\end{abstract}

\section{果実破砕時に起こる醭素的褐変は，果汁の外観的品質} を損なうばかりでなく，褐変物質の重合に上る Offflavor よ゙香味の劣化を招くことが知られておりり2), これを防止するためには果実に存在するポリフェノール オキシターゼ (PPO) 活性を抑制する必要がある. PPO 不活性化の最も効果的な力法は加熱操作であるが, 果実破碎時の工程や果汁の品質を考虑すると，できるだ け温和な条件が好ましいことは言うまであない，特に最 近は天然果汁やフローズンあるいはチルド果汁の需要が 高まり，例えば米国ではフレッシュスクイズオレンジジ ュースが搾りたてのジュースとして人気を博しており゙，
生果実の特性をできるだけ活かす加工法が要求されてい る. 未加熱状態での PPO 活性の抑制には，アスコルビ ン酸やエリソルビン酸24)5), 亚硫酸(6)7)，アスコルビン 酸の各種誘導体や脂肪酸エステルの添加 ${ }^{8) ~ 10)}$ に上る効 果が検討されているが, 果汁中でのこれらの酸化物の品 質への影響や食品添加物としての表示などの問題が残る.

著者らはスモモの一品種 ‘サンタローザ’が破研時に ほとんど褐変しないことを報告"1)し，この原因が，こ の品種自身のアセトン可溶性画分に存在する PPO 阻害 物質によることを明らかにしてて苜然阻害剂としての 利用を試みた。一方, 中林 ${ }^{13)}, \mathrm{CHUNG}^{14)}$, ScIANCALE-

“山梨県工業技術センター食品・䤑造部（テ406 山梨県東八代郡石和町窪中島 312-4）

** 大阪府立大学農学部（宁591 大阪府堺市百舌鳥梅町 4 丁 804） 
PORE ら ${ }^{15)}$ が桃よオリーブを用いた報告では，醉素的褐 変の程度はポリフェノール含量に支配されるとしている. しかし，著者の報告によって，果実あるいは品種によっ て醉素的褐変の支配因子の異なることが示唆された。

本報では数種の果実のアセトン可溶性画分と PPO を 調製して酵素的褐変を起こし，果実間の褐変の差異や阻 害効果を検討し, 果実成分の天然阻害剤としての利用や 異種果実を同時に破砕した場合の褐変予測の基礎資料を 得るために実施した研究結果について報告する.

\section{実 験 方 法}

\section{1. 供試材料}

ブドゥは山梨県石和町産の ‘デラウェアー’，スモモ は同若草町産の ‘ソルダム’，モモ‘白鳳’，リンゴ‘つが る’及びナシ ‘幸水’は石和町内の市販品を購入し，合 計 5 属 5 品種の果実を供試した。

2. アセトンパウターの調製

果肉部約 $100 \mathrm{~g}$ を $-40^{\circ} \mathrm{C}$ に冷却した 10 倍量のアセ卜 ンととあにホモジナイズし，ブフナー沪過器により素早 く汇過した．残渣は少量のアセトンで洗って一夜減圧乾 燥し, 得られたパウダーはデシケーターに入れて使用時 までー $20^{\circ} \mathrm{C}$ の冷凍庫に保存した。

\section{3. アセトン可溶性画分の調製}

供試果実約 $50 \mathrm{~g}$ （ブドウは全粒，その他の果実は中 心部と外側のほぼ中間部を輪切りにし，果肉と果皮を含 めたが種子や果芯は含まない）をそのままあるいは細断 後, 中林の方法 ${ }^{16)}$ に準じて $150 \mathrm{ml}$ のアセトンととも にホモジナイズした後加熱還流抽出した，沪過後残渣を $70 \%$ のアセトンで 2 回還流抽出し，全抽出液は合せて 炭酸ガスで置換後 $40^{\circ} \mathrm{C}$ 以下で滅圧濃縮した。濃縮液は $12000 \times \mathrm{g}, 10$ 分間の遠心分離後 $100 \mathrm{~m} l$ に定容した. なお，以後この画分をポリフェノール抽出液または抽出 液とした。

\section{4. 粗酥素液の調製}

アセトンパウダーを一定量採取しここれ 70 倍量の $1 / 20 \mathrm{M}$ クエン酸- $1 / 10 \mathrm{M}$ リン酸緩衝夜 $(\mathrm{pH}$ 5.0) を加 えて $4^{\circ} \mathrm{C}$ 下で 1 時間時々擋找しながら抽出した後 $12000 \times \mathrm{g}$ で遠心分離した，得られた上澄液を粗醉素液 とした.

\section{5. 抽出夜の褐変度の測定}

ポリフェノール含量が $0.275 \mathrm{mg}$ になるように抽出 液 $(0.1 \sim 0.6 \mathrm{ml})$ を採取し, $1 / 20 \mathrm{M}$ クエン酸 $-1 / 10 \mathrm{M}$ リン酸㗔衝液（pH 5.0）を $0.4 \sim 0.9 \mathrm{ml}, 0.5 \mathrm{~g}$ のパウ ダーから同じ緩衝液で抽出した粗醉素液 $2 \mathrm{~m} l$ の合計
$3 \mathrm{ml}$ をガラスセルに入れ， $30^{\circ} \mathrm{C}$ で反応させた，経時的 に 2 倍量の $99.5 \%$ のメタノールを加えて反応を停止さ 女, $12000 \times \mathrm{g}, 10$ 分間遠心分離後 $400 \mathrm{~nm}$ の吸光度を 測定し ${ }^{11)}$ ，反応開始前の吸光度との差を褐变度とした。

\section{PPO の活性汶定}

ワールブルク検圧計を用い，アセトンパウダー $0.5 \mathrm{~g}$ から抽出した粗酵素液 $1 \mathrm{ml}$ と $\mathrm{pH} 5.0$ のクエン酸り ン酸緩衝液 $1 \mathrm{ml}$ を主室に，基質（カテコール，カテキ ン，クロロゲン酸，ピロガロール，いずれも $4 \times 10^{-6}$ $\mathrm{mol}) 1 \mathrm{~m} l$ を側室に，副室には $0.1 \mathrm{~m} l$ の $20 \% \mathrm{KOH}$ 溶液をとり 10 分間空振りした後側室の基質を醉素液に 添加し， $30^{\circ} \mathrm{C}$ で経時的に酸素吸収量を測定した.

\section{7. 抽出液と PPO 反応系におけるクロロゲン酸の䤇} 化度合の測定

適当量のアセトンパウダーから抽出した粗醭素液の各 果実 $0.1 \mathrm{~g}$ 相当量を採取 $(0.15 \sim 0.49 \mathrm{ml})$ し，これに 果実 $0.1 \mathrm{~g}$ 相当のポリフェノール抽出液 $(0.1 \sim 0.2 \mathrm{~m} l)$ とクロロゲン酸 $(0.1 \mathrm{mg} / \mathrm{ml}) 0.5 \mathrm{ml}$ 及び上記 $\mathrm{pH}$ 5.0 の緩衝液を加えて計 $3 \mathrm{ml}$ とし，ガラスセル内，30 ${ }^{\circ} \mathrm{C}$ で反応させた. 反応の停止は 4 項之同様な方法で行 って遠心分離後 $400 \mathrm{~nm}$ の吸光度を測定し, 対照とし てクロロゲン酸を含まない反応系の吸光度との差を酸化 度合の指標とした。

\section{8. ポリフェノール成分の定量}

既報 ${ }^{11}$ に準じ，抽出液中の全ポリフェノールは FOLIN-DenIS 法, フラバノール型タンニンはバニリン 一硫酸法，クロロゲン酸はジアゾ法を用いて定量した. ロイコアントシアンは，抽出液を 5 倍に希釈し，その 1 $\mathrm{m} l$ を堤酸一ブタノール法により発色し， $550 \mathrm{~nm}$ の吸 光度を求め, この值を果実 $100 \mathrm{~g}$ に換算して示した.

\section{実 験 䊅 果}

1. 種類の異なる果実のポリフェノール抽出液と PPO の褐変反応

ブドウ，スモモ及びモモから抽出した抽出液と同時に 各果実から調製したPPO の褐变反応の結果を Fig. 1 に示した.いずれの PPO を用いてもブドゥの抽出波の 褐変が顕著に抑制され，モモの抽出液の裮変が最む大き かった．スモモの抽出液は両者の中間程度の蝎変であっ たが，PPOによって若干差異がみられ，ブドウで估䄍 変は促進された，褐変反応の基質である含有ポリフェ 一ルは同一であることからこの差は抽出液成分あるいは ポリフェノール成分組成に起因しているのではないかと 思われた。 
なお，各反応液の実際の $\mathrm{pH}$ は 4.85〜 5.0の範囲で おった.

\section{2. ポリフェノール抽出液の成分組成}

果実間の褐変の差の一つの理由としてポリフェノール 成分組成が考えられたので，上記 3 種類の果実以外にり ンコとナシを加え, Table 1 にその結果を示したが, 全ポリフェノール含量には大差が見られた．組成的に見 ると，ブドウ，スモモ，及びモモの 3 種類ではブドゥの フラバノール型タンニンとスモモのクロロゲン酸の組成 が低く，また，モモの褐变基質の一つとして知られてい $ろ^{16)}$ ロイコアントシアンは少なく，褐変の程度とポリ フェノール含量及び組成の間に相関関係が見られず，ポ リフェノール含量や組成が 3 種類の果実間の褐変度の差 異を生ずる主要因ではないと思われた。 リンゴとナシで は、ナシの含量が影著に少なく, フラバノール型タンニ
ンとクロロゲン酸の組成比が他の果実の $1 / 2$ と低かった. リンゴの組成比は他の果実と大差はなかった.

\section{PPO の基質特異性}

各果実抽出液の PPOによる醭素的褐変に与える影響 を調べるため，PPO が最すよく酸化する基質を選択し た. モモとブドウの例を Fig. 2 に示したが，クロロゲ ン酸を最もよく酸化し，次いで果実によって異なるが， カテコールとD-カテキンで, O-diphenol 類をよく酸 化した. ピロガロールは酸化しにくかった．他の果実す 程度の差はあったが, 同様な傾向であり，この結果から クロロゲン酸の酸化を褐変の指標とした。
4. ポリフェノール抽出液が PPO のクロロゲン酸の 酸化・蝎変に与える影赠
(1) ‘ソルダム’ スモモの PPO

結果を Fig. 3 に示した. ソルダムの PPO はナシ以
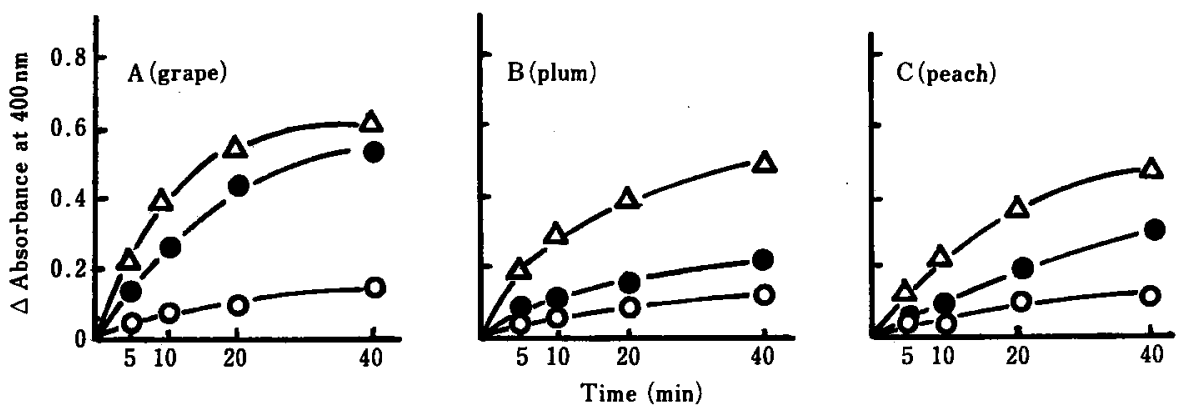

Fig. 1 Changes of $\triangle \mathrm{OD}_{400}$ in the reaction mixture of each acetone powder and polyphenol extracts $(O-O$ grape, - plum, $\triangle-\triangle$ peach) from three kinds of fruit

$\triangle \mathrm{OD}_{400}=\mathrm{OD}_{400}$ after reaction- $\mathrm{OD}_{400}$ before reaction

Acetone soluble fraction of fruit was designated as polyphenol extract.

$A, B$ and $C$ show the acetone powder from grape, plum and peach, respectively.

All reaction mixtures contained $0.275 \mathrm{mg}$ of total polyphenol.

Composition of reaction mixture; $1 / 20 \mathrm{M}$ citrate-1/10 $\mathrm{M}$ phosphate buffer ( $\mathrm{pH} 5.0$ ) $0.4-0.9$ $\mathrm{m} l$, polyphenol extract $0.1-0.6 \mathrm{~m} l$, crude enzyme sol. $2 \mathrm{~m} l(0.5 \mathrm{~g}$ of each acetone powder was extracted with above buffer $35 \mathrm{ml}$ ) Total $3 \mathrm{ml}$. Reaction temperature was $30^{\circ} \mathrm{C}$.

Table 1 Polyphenol contents in various fruits

\begin{tabular}{lcrrr}
\hline Fruits & $\begin{array}{c}\text { Total } \\
\text { polyphenol }\end{array}$ & $\begin{array}{c}\text { Flavanol } \\
\text { tannin* }\end{array}$ & $\begin{array}{c}\text { Chlorogenic } \\
\text { acid** }\end{array}$ & $\begin{array}{l}\text { Leuco anthocyan } \\
\text { Absorb. at 550 nm }\end{array}$ \\
\hline Plum (Sordum) & 454 & $246(54.1)$ & $158(34.8)$ & 0.740 \\
Peach (Hakuho) & 92 & $46(50.0)$ & $72(78.3)$ & 0.130 \\
Grape (Delaware) & 290 & $100(34.5)$ & $236(81.4)$ & 0.456 \\
Apple (Tsugaru) & 68 & $38(55.9)$ & $44(64.7)$ & 0.098 \\
Pear (Kosui) & 18 & $4(22.2)$ & $8(44.4)$ & 0.003 \\
\hline
\end{tabular}

*as catechin (mg/100 g flesh), ${ }^{* *} \mathrm{mg} / 100 \mathrm{~g}$ flesh, ${ }^{* * *}$ absorbance $/ 100 \mathrm{~g}$ flesh

The values in parentheses show the percentage to the total polyphenol. 


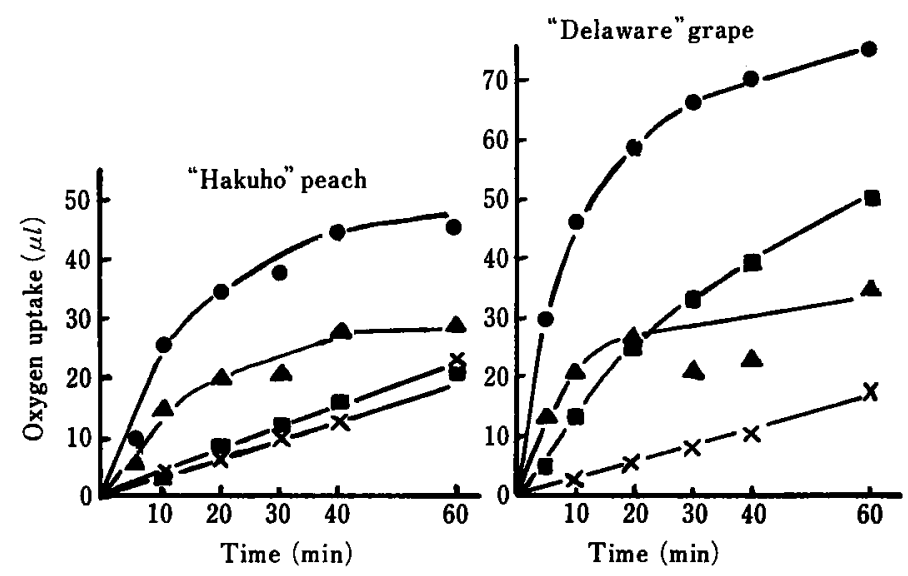

Fig. 2 Oxygen uptake of the reaction mixture of the acetone powder from 'Delaware' grape and 'Hakuho' peach and several substrates
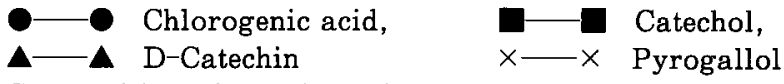

Composition of reaction mixture ;

$1 / 20 \mathrm{M}$ citrate $-1 / 10 \mathrm{M}$ phosphate buffer $1 \mathrm{ml}$

Substrate $\left(4 \times 10^{-6} \mathrm{~mol}\right) \quad 1 \mathrm{ml}$

Crude enzyme sol. $(0.5 \mathrm{~g}$ of each acetone powder $1 \mathrm{ml}$

was extracted with above buffer $35 \mathrm{ml}$ )

Total $3 \mathrm{~m} l$

Reaction temperature was $30^{\circ} \mathrm{C}$.

外の果実の抽出液の存在下でクロロゲン酸をよく酸化し, 抽出液の存在が褐変を促進する傾向のあることがわかっ た. 特にンルダム自身の抽出液す促進し，最もその効果 の大きかったのはリンゴの抽出液であった。

(2) ‘白鳳'モモの PPO

結果を Fig. 4 に示した. 白鳳の PPO はソルダムと 異なり，ナシ以外の果実の抽出液はいずれあクロロゲン 酸の酸化を抑制した，特にブドウとスモモの褐変抑制効 果は大きく，対照の $1 / 2 \sim 1 / 3$ 程度に抑制した. モモ自 身の抽出液も若干抑制傾向を示した，リンゴは対照と大 差はなかった。

（3）“幸水”ナシの PPO

結果は Fig. 5 に示した. 幸水の PPO は, ソルダム と同様にナシ自身以外の抽出液の存在下でクロロゲン酸 の酸化・褐変が促進された。しかし，ブドゥの抽出液で はその樣相が異なり，反応当初は，その速度が㧩制され る傾向にあり，時間の経過とともに促進された，最も促 進したのはスモモの抽出液であり，40 分後にはブドウ の抽出液むこれに次いだ。ナシ自身の抽出液は対照と大
差はなかった.

(4) ‘つがる’リンゴの PPO

結果は Fig. 6 に示した。 つがるは抽出液の種類によ り促進される場合と抑制される場合があった，スもと ブドゥの抽出液は顕著にクロロゲン酸の酸化・褐変を抑 制したが，リンゴとモモは促進した．ナシは対照と大き な差はなかった。

(5) ‘デラウェアー’ブドゥの PPO

結果は Fig. 7 に示した. デラウェアーのPPO はそ れ自身の抽出液で顕著にクロロゲン酸の酸化・褐変を抑 制し，対照の $1 / 3$ 程度の褐变抑制効果が認められた。他 の果実の抽出液は一時的に促進効果があったが対照との 差はわずかであった.

考察

ポリフェノール含量を一定にした 3 種類の果実加らの アセトン可溶性画分に，それぞれの果実からのPPOを 作用させると，抽出液の褐变には大きな差がみられ，見 掛けの上ではポリフェノール含量以外の可溶性成分が 


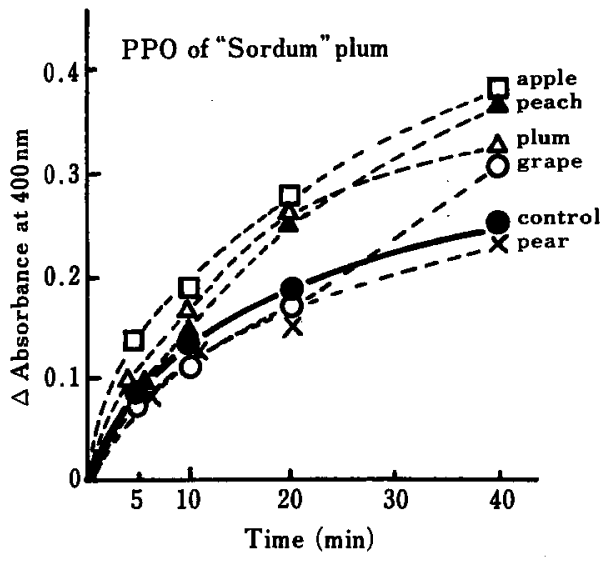

Fig. 3 Effect of addition of polyphenol extracts from various fruits on the enzymatic browning of chlorogenic acid containing PPO of 'Sordum' plum

$\triangle$ Absorbance was shown as differences of absorbance at $400 \mathrm{~nm}$ with and without chlorogenic acid

Composition of reaction mixture ;

crude enzyme corresponding to $0.1 \mathrm{~g}$ of fruit

polyphenol extract corresponding to $0.1 \mathrm{~g}$ of fruit

chlorogenic acid $(50 \mathrm{mg} / 50 \mathrm{~m} l) \quad 0.5 \mathrm{~m} l$ $1 / 20 \mathrm{M}$ citrate $-1 / 10 \mathrm{M}$ phosphate buffer (pH 5.0)

total
Reaction temperature $; 30^{\circ} \mathrm{C}$

$1.8 \sim 2.4 \mathrm{ml}$

PPO の活性を阻害しているものと推察された（Fig. 1).

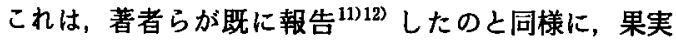
の種類間にも褐变の程度がポリフェノール含量に支配さ れない反応系の存在が推察された，従来の報告 ${ }^{13)}$ 15) は同種類の果実間ではポリフェノール含量が褐変を支配 しているとの䢁告が多かったが，今回のポリフェノール 成分の組成調查加らも，例元ば，褐変の最も激しいモモ がロイコアントシアンが少なかったことや全ボリフェ， 一ル含量が最も多いのにあかかわらず，モモより褐変程 度が小さかったことなど, ポリフェノール含量以外の要 因の可能性肪あるるのと思われた。

そこで，さらにこの現象を明確にするため，各果実の 抽出液と PPO との反応系に扔けるクロロゲン酸の酸化 を裮変の指標として調べた（Fig. 3〜7）結果を一覧表

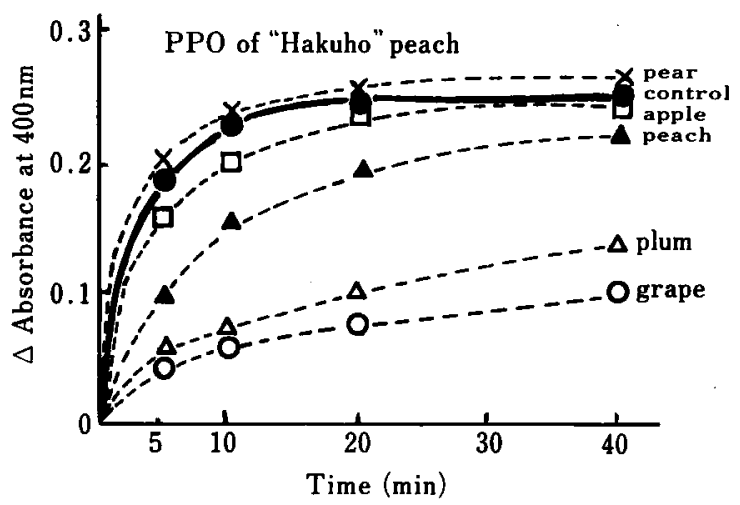

Fig. 4 Effect of addition of polyphenol extracts from various fruits on the enzymatic browning of chlorogenic acid containing PPO of 'Hakuho' peach

Reaction conditions and measuring methods are the same as given in Fig. 2.

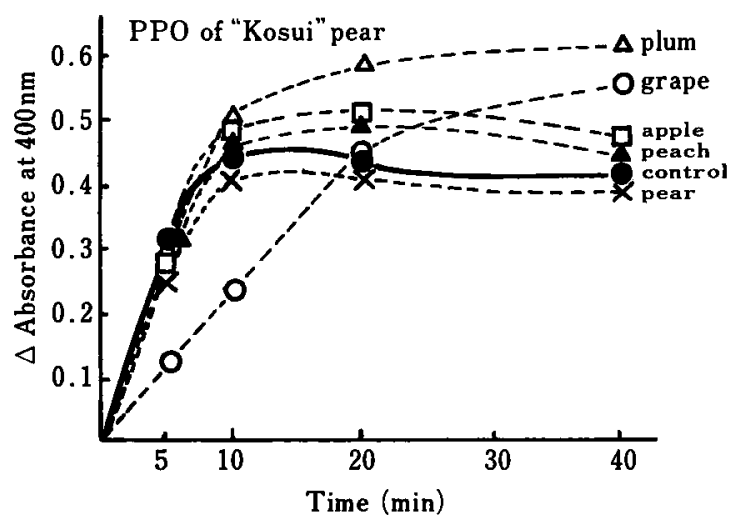

Fig. 5 Effect of addition of polyphenol extracts from various fruits on the enzymatic browning of chlorogenic acid containing PPO of 'Kosui' pear

Reaction conditions and measuring methods are the same as given in Fig. 2.

にして Table 2 に示した．対照はクロロゲン酸を添加 しない反応系を用いたが，モモ，リンゴ及びナシの PPO に対してブドゥの抽出液は顕著に阻害効果を示し た。 また，スモモの抽出液はモモとリンゴの PPO に対 して阻害勃果を示したが，ナシ，スモモ，フドゥの PPO には, 促進効果を示し, PPO の種類による効果 に差のあることがわかった，さらにモモとリンゴの抽出 
液は褐変促進効果を示す因子を保有しているすのと考え られ,ナシはあまり影響を及ぼさないように思われた。 一方この反応を $\mathrm{PPO}$ の性質から見ると，スモモは各抽 出液によって活性化され易いと考えられ，リンゴやブド ウは抽出液によって阻害される場合と活性化される場合 のあることがわかった. 果実抽出液の添加比率は果実重 量に換算して全て同量にしてあるので，これらの差は果 実間の差異と考えられる. 実際の果実の破砕が混合系で 行われることは少ないと考えられるが, “デラウェアー” ブドウ抽出液の場合には少なくともここで示した他の果 実の PPO 阻害剤としては利用できるあのと考えられる. ブドウ破砕時の PPO の酸素消費速度 ${ }^{7)}$ や褐変度 ${ }^{17)}$, RADLER ら ${ }^{18)}$ の報告などから，ブドウの PPO 活性は 高いことが指摘されており，本報で用いたデラウェアー 種とは異なった，これは，品種の違いああるが，これま での報告では PPO の性質のみの測定で, 抽出液との反

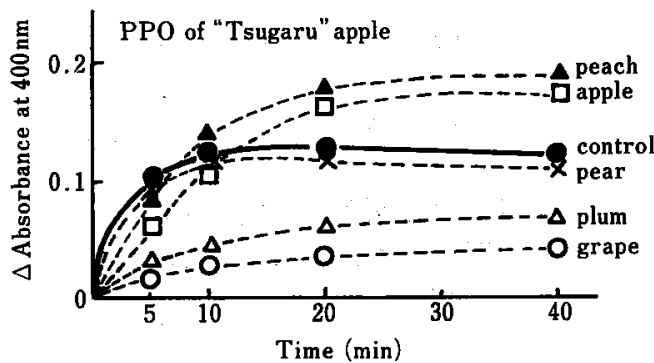

Fig. 6 Effect of addition of polyphenol extracts from various fruits on the enzymatic browning of chlorogenic acid containing PPO of 'Tsugaru' apple

Reaction conditions and measuring methods are the same as given in Fig. 2.
応は行われていないことに起因しているものと思われ， 破砕液の褐変の程度と PPO 活性との間には大きな差も 予想されるが，今後各種のブドゥの PPO とそれぞれの 抽出液との関係についてあ詳細に検討する必要があるも のと思われた。

なお，PPO 活性の促進効果の原因についてはさらに 検討を続ける予定である。

\section{要約}

ブドゥ“デラウェアー’, スモモ‘ソルダム’, モモ‘白 鳳'果実加らPPO とアセトン可溶性画分 (抽出液)を

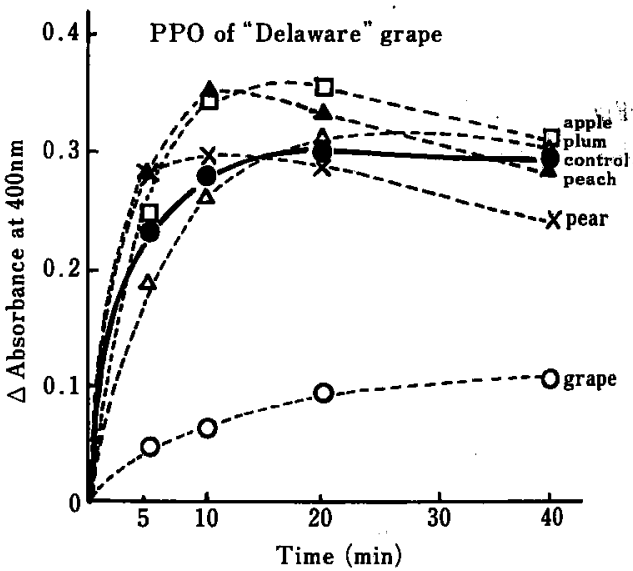

Fig. 7 Effect of addition of polyphenol extrcts from various fruits on the enzymatic browning of chlorogenic acid containing PPO of 'Delaware' grape

Reaction conditions and measuring methods are the same as given in Fig. 2.

Table 2 Influence of polyphenol extracts on the enzymatic browning

\begin{tabular}{lccccc}
\hline \hline \multirow{2}{*}{$\begin{array}{l}\text { Acetone soluble } \\
\text { fractions }\end{array}$} & \multicolumn{5}{c}{ Degree of influence } \\
\cline { 2 - 6 } & Peach* & Apple* & Pear* & Plum* & Grape* \\
\hline Peach (Hakuho) & - & -- & - & -- & $-(-)$ \\
Apple (Tsugaru) & - & -- & - & -- & $-(--)$ \\
Pear (Kosui) & - & - & - & -- & + \\
Plum (Sordum) & + & + & -- & -- & - \\
Grape (Delaware) & $H$ & + & $--(+)$ & - & $\#$ \\
\hline
\end{tabular}

* Acetone powder from various fruits

$+(25 \sim 50 \%), H(50 \sim 100 \%)$, \#(100\% ); Degree of inhibition

- ; Non inhibition, --(25\% ); Acceleration of the browning

Symbols in parentheses show the degree of the inhibition and acceleration at the end of the reaction. 
調製し，各 PPO に抽出液を反応させた．その結果，ブ ドゥの抽出液は各 PPO の活性を顕著に抑制し，モモの 抽出液はよく酸化された。.スモモはその中間であった。

これらの果実にナシ“幸水’，リンゴつがる’を加え てPPO と抽出液を調製し，基質特異性の高いクロロゲ ン酸を添加して抽出液のクロロゲン酸の酸化に与える影 帮を調べた. ブドゥの抽出液はモモ，リンゴ及びブドウ のPPO を顕著に阻害した，スモモの抽出液はモモとり ンゴの PPO を阻害したが, ナシ，スモモ及びブドゥの PPOには促進効果を示した. モモとリンゴの抽出液に はPPO の促進効果が大きかった.

\section{文献}

1) Vamos-Vigyazo, L., Mihalyi, K., Gajzago I., and NadVARI-Markus N.: Acta Alimentaria, 6 (4), 379 (1977).

2). 中林敏郎 : 日食工誌, 10, 530 (1977).

3）伊福 靖: 食品と科学, 31 (2)，81（1989）.

4) SAPERS G.M. and Douglas JR. F.M. : $J$. Food Sci., 52, 1258 (1987).

5) SAPERS G.M. and Ziolkowski, M.A.: $J$. Food Sci., 52, 1732 (1987).

6) Sayavedra-Soto L.A. and Montgomery : J. Food Sci., 51, 1531 (1986).

7）天野義文 -久保田正俊 - 加賀美元男 : 醉醉工学,
57, 92 (1979).

8) Sapers G.M., Hicks K.B., Philips J.G., Garzarella L., Pondish D.L., Matulaitis R.M., McCormack. J., Sondey S.M., SeIb P.A. and EI-Atwy Y.S. : J. Food Sci., 54, 997 (1989).

9) SAPERS G.M., EI-AtwY Y.S., Hicks K.B. and Garzarella L. : J. Food Sci., 54, 1096 (1989).

10) Hsu A.F., SHIEH J.J., Bills D.D. and White K. : J. Food Sci., 53, 755 (1988).

11）小宮山美弘・原川 守-过 政雄 : 日食工誌，26, 325 (1979).

12) Komiyama. Y., Harakawa $M$. and TsujI M, : Agric. Biol. Chem., 44, 937 (1980).

13）中林敏郎・鵜飼暢雄 : 日食工誌，10，211 (1963).

14) Chung J.I. and LuH B.S. : Confructa, 17, 8 (1972).

15) Sciancalepore V.: J. Food Sci., 50, 1194 (1985).

16）中林敏郎：日食工誌, 15, 73 (1968).

17) Valero E., Varon $R$. and GarciaCarmona: J. Food Sci. 53, 1482 (1988).

18) Radler F. and Torokfalvy E. : Z. Lebensmite U., 152, 38 (1973).

(平成 2 年 7 月 11 日受理) 